\title{
Field scale study on efficacy of miticide, against two spotted mites in Kenyanagro climatic zone
}

\author{
Patil Satilal Bhika \\ ${ }^{I}$ 8D, Raisoni Industrial Park, Opp. Kirpekar Engineering, Near Honeywell, Rajiv Gandhi IT-BT Park, Phase- \\ II, Village- Maan, Tal-Mulshi, Dist- Pune-411057, Maharashtra, India.
}

\begin{abstract}
Two spotted spider mites (TSM)is an incident pest problem in Kenyan roses cultivators due to the climatic conditions. Paradigm shift from chemical to bio pesticide is at most important in order to reduce the threat to the environment and human health. This research is aimed to confirm the potency of contact botanical pesticide to be used as bio control againstspider mite at Kenyanagro climatic zone. Commercially available and proven chemical pesticides were used to access the efficacy of this botanical pesticide. M Impact, a botanical pesticide was analyzed for its effect on two spotted spider mites at field level on one acre one green houseand its effect was compared with the available chemical pesticides. M impact was found to be most effective in terms of its period of action and potency against two spotted mites, while other chemical miticides showed delayed effect due to their different mode of action.
\end{abstract}

Keywords: Rose, Kenya, M impact, Two spotted mite

\section{Introduction}

Rose is major crop inKenyanfloriculture business involving $61 \%$ share in floriculture. Kenya is the leading exporter of rosescut flowers to the European Union (EU). According to horticulture-validated report 2012, the main cut flowers grown in Kenya are roses (53.6\%), which is highest amongst the other floriculture values. The main production areas are around Lake Naivasha, Mount Kenya, Nairobi, Thika, Kiambu, Athi River, Kajiado, Kitale, Nakuru, Kericho, Nyandarua, Trans Nzoia, UasinGichu and Eastern Kenya.

Major anthropogenic activities in Kenyan agro climatic conditions are due to shift in temperature and rainfall. Regular pest control methods involve chemical pesticides having high potency and fast action against the pest.Two-spotted spider mite (TSM), Tetranychusurticae Koch, 1836, belongs to the group of acarines known as Acariformes, in the suborder Prostigmata, and the family Tetranychidae [1]. Concerns about the use of agrochemical control measures have led to search for alternative control measures to suppress TSM populations, including the use of biological control, particularly by applying predatory phytoseiulus mites [2] For a sustainable solution of agricultural pest botanical pesticides are known to be arecommended product. Numbers of characters like its biodegradable nature systemicity after application, favorable safety profile are used for this choice over the chemical pesticides [3]. Nonetheless, the control provided by predatory mites is often insufficient and supplementary sprays with selective chemicalacaricides have beenrequired [4]. Botanical pesticides have been shown to be effective at reducing spider mite populations. For example, Cote et al. 2002 found that one of the botanical preparation caused significant mortality to spider mites, $40 \%$ dead compared to less than $10 \%$ dead in control. The effect of these pesticides however was short-lived, as mortality was equal in control and treatments by 3 days. These botanical pesticides were not toxic to predator mites [5].

Considering this present study was aimed towards checking the efficacy of the botanical pesticide $\mathrm{M}$ impact against the regular chemical pesticides. Since chemical pesticides are known to have direct effect on pests and its potency is well recorded, it was thought worthwhile to compare efficacy of botanical pesticide with known chemical based pesticides. Well defined and proven chemical pesticides(Mentioned in Table 1) were taken along with botanical pesticide M impact.

\section{Materials and methods}

One acre green house with Tetranychusurticaeaffectedrose (variety- Gold strike) plantation at Athi River, central Kenyawas selected for the efficacy trials. Total plot was divided in eight plots using randomized block design and labeled as per the treatment along with water control. Treatment was given with various pesticides in spray method at specified concentrations i.e. Kelthane $(1.5 \mathrm{ml})$, Vertimec $(0.4 \mathrm{ml})$, Magister $(1 \mathrm{ml})$, Omite $(1 \mathrm{ml})$, Missile $(0.5 \mathrm{gm}$.), M-Impact $(1 \mathrm{ml})$ per liter of water. $\mathrm{pH}$ of the spray solution was maintain between 5 to 7 with the help of sulphuric acid (1N). Details are mentioned in Table 1. 
Table 1: Details of the products and their concentration used for control of mites

\begin{tabular}{|c|c|c|c|c|}
\hline Product & Active Ingredient & Type & Dose/lit & Company \\
\hline Kelthane & Dicofol & Chemical & $1.5 \mathrm{ml}$ & Insecticides India Ltd. \\
\hline Vertimec & Abamactin & Chemical & $0.4 \mathrm{ml}$ & Syngenta India \\
\hline Magister & Fenazaquin & Chemical & $1 \mathrm{ml}$ & Dow Agro Sciences \\
\hline Omite & Propergite & Chemical & $1 \mathrm{ml}$ & Dhanuka \\
\hline Missile & Abamectin & Chemical & $0.5 \mathrm{gm}$ & $\begin{array}{c}\text { Crystal Crop Protection Pvt. } \\
\text { Ltd. }\end{array}$ \\
\hline M-Impact & Botanical extracts & Botanical/biopesticide & $1 \mathrm{ml}$ & $\begin{array}{c}\text { GreenVision Life Sciences Pvt. } \\
\text { Ltd }\end{array}$ \\
\hline
\end{tabular}

Power spray with pressure of 20 bars was applied during the treatment. Water was used as aexperimental control.Results were taken in terms of count. Immediate count was taken and continued for various time interval. Observations for the density of mites in terms of total number of mites per plant at different time intervals up to 12 hours were taken. Plants were also checked morphologically for any phytotoxicitysymptoms.

\section{Results}

Continuous reduction in the density of TSM was observed after the spray on infected rose plant. Although chemical treatments are reducing the mite density, botanical miticide is showing highest mortality on two spotted spider mite. Hence it was further evaluated for the phytotoxicity on plants using higher concentrations. It was observed that more than $3 \mathrm{ml} /$ liter dose shows scorching symptoms on tender leaves.

\section{Mites:}

Area treated: One acre Greenhouse

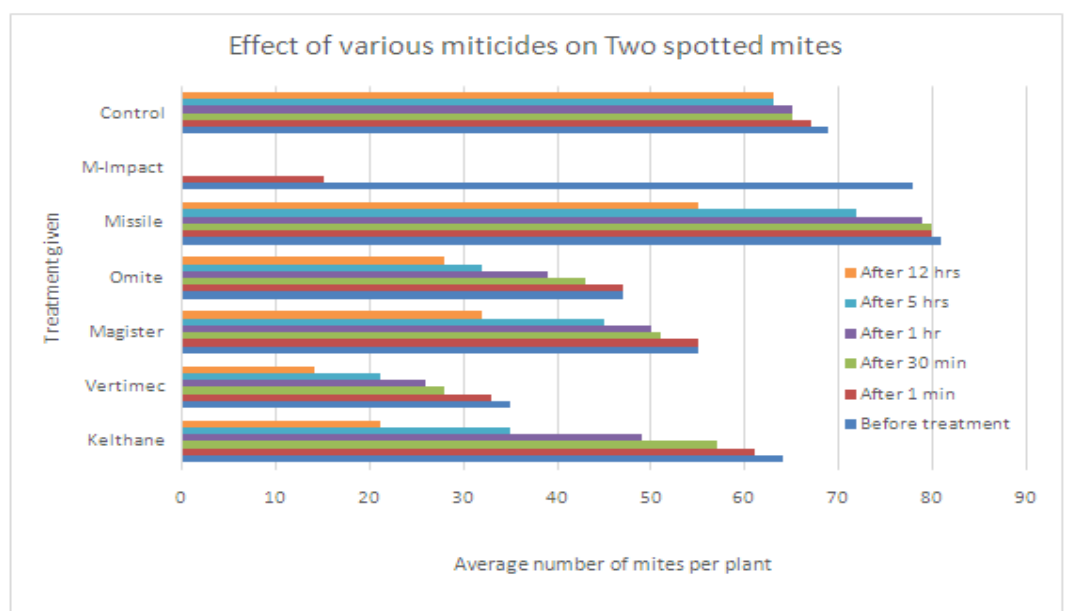

Figure 1 Effect of different miticides on Spider mite control at various time intervals (all values are average values)

\section{Discussion}

The effect of sprays on mite populations varied over the seventypes of treatment heads. In each of the chemical treatment even after 12 hours reduction was observed up to nearly $50 \%$. i.e. rate of mortality in all other chemical treatment is approximately up to $50 \%$. Botanical pesticide used was $\mathrm{M}$ impact which shows $100 \%$ mortality within one minute of contact period. This reflects very high potency of this pesticides. Mechanism of action on mites was different using chemical and bio pesticides. Most of the chemical pesticides affect are observed once the mite consumes the chemicals. M impact is a botanical pesticide and has contact poisoning effect. This may be areason for getting highest mortality in $\mathrm{M}$ impact and slow but steady reduction of mites in chemical pesticides used during the study.

\section{Conclusion}

M Impact destroys all mites present on the plant in very less time and did not cause any phytotoxicity in a rose plant. In general, $M$ impact was found to be a suitable option for field-scale integrated pest management programs for controlling two spotted spider mites on greenhouse horticultural plant i.e. rose plant at Kenyan agro climatic zone. 


\section{References:}

[1] Dupont, L.M.,On gene flow between Tetranychusurticae Koch, 1836 and cinnabarinus (Boisduval) Boudreau, (Acari: Tetranychidae): synonymy between the two species. Entomol. Exp. Appl., 1979, 25:297-303.

[2] McMurtry J and Croft B Lyfe styles of phytoseiid mites and their roles in biological control, Annual Review of Entomology 1997 42, 291-321

[3] Dubey N, RavindraShukla, Ashok kumar, BhanuPrakash, Prospects of botanical pesticides in sustainable agriculture, Current Science, 98 (4), 2010. 479-480

[4] Jacobson R, Croft P,Fenlon J., Response to fenbutatin oxide in populations of Tetranychusurticae Koch (Acari: Tetranychidae) in UK protected crops Crop Protection, 18 (1), 1999, 47-52

[5] Cote, K., Lewis E, and Shultz P. Compatibility of acaricide residues with Phytoseiuluspersimilis and their effects on Tetranychusurticae. Horticulture Science37(6)2002, 906-909.

[6] El Shafie, H.A.F., and T. Basedow., The efficacy of different neem preparations for the control of insects damaging potatoes and eggplants in the Sudan. Crop Protection 22(8), 2003 :1015- 1021.

[7] Nauen, R., Elbert, A., McCaffery, A., Slater, R. and Sparks, T. C, IRAC: Insecticide Resistance, and Mode of Action Classification of Insecticides, in Modern Crop Protection Compounds, Volumes 1-3, Second Edition (eds W. Krämer, U. Schirmer, P. Jeschke and M. Witschel), Wiley-VCH Verlag GmbH \& Co. KGaA, Weinheim, Germany.2012 doi: 10.1002/9783527644179.ch27

[8] D Perdikis, E Kapaxidi, G Papadoulis Biological control of Insect and Mite Pests in greenhouse solanaceous crops, 2008. The European journal of plant science and biotechnology, 2, 125-144

[9] A. Gonzalez-Coloma, M. Reina, C.E. Diaz, B.M. Fraga, O. Santana-MeridasNatural Product-Based Biopesticides for Insect Control Reference Module in Chemistry, Molecular Sciences and Chemical Engineering, 2013 